возложить данные обязанности, видятся специально аккредитованные органы сертификации.

$$
* * *
$$

1. Гражданский кодекс Российской Федерации (часть четвертая) от $18.12 .2006 \mathrm{~N} 230-$ Ф3 (ред. от 18.07.2019) //С3 РФ. 25.12.2006, N52 (1 ч.), ст. 5496.

2. Постановление Седьмого арбитражного апелляционного суда по делу № А45- 14505/2018 // sudact.ru - сайт. Режим доступа https://sudact.ru/arbitral/doc/CZMoHes5FBo5/

3. Попова А. В., Матасова А. О. Некоторые проблемы защиты товарного знака // Молодой ученый. -2019. 一№4. C. 322-323.

\title{
Мудрая Д.А. \\ Средства индивидуализации, содержащие географические обозначения, в законодательстве стран СНГ
}

Дальневосточный федеральный университет (Россия, Владивосток)

doi: 10.18411/lj-04-2021-240

\section{Аннотация}

В статье приводятся результаты анализа законодательства стран-участниц СНГ в свете принятия в 2010 г. Межпарламентской Ассамблеей государств - участников СНГ Модельного Кодекса интеллектуальной собственности, имеющего целью приведение в единообразие национальных законодательств.

Ключевые слова: средства индивидуализации товаров, гражданское законодательство, наименование места происхождения товаров, СНГ, географические указания

\section{Abstract}

The article presents the results of the analysis of the legislation of the CIS member states in the light of the adoption in 2010 by the Interparliamentary Assembly of the CIS member states of the Model Code of Intellectual Property, aimed at bringing national legislations into uniformity.

Keywords: means of individualization of goods, civil law, appellation of origin of goods, CIS, geographical indications

Одним из приоритетных направлений российской внешней политики является сотрудничество с государствами-участниками Содружества Независимых Государств (далее по тексту - СНГ) в двустороннем и многостороннем формате. Одним из направлений экономической интеграции в рамках СНГ является создание цивилизованного рынка интеллектуальной собственности. Необходимым условием данного процесса служит унификация соответствующих правовых норм и гармонизация внутригосударственного законодательства. Гармонизация национальных законодательств обеспечивается в странах СНГ координацией законопроектной работы, принятием согласованных актов национального законодательства, проведением предварительной экспертизы законопроектов на соответствие их нормам международного права и документам, принятым в рамках объединения [1].

В том числе, с целью обеспечения единообразного регулирования имущественных и связанных с ними личных неимущественных отношений, возникающих в связи с созданием и использованием объектов интеллектуальной собственности, распоряжением правами интеллектуальной собственности, охраной и защитой прав на такие объекты, а также с целью гармонизации национальных законодательств в сфере интеллектуальной собственности в 2010 г. Межпарламентской 
Ассамблеей государств - участников СНГ был разработан и принят Модельный Кодекс интеллектуальной собственности (далее - Модельный Кодекс, Кодекс) [2].

При этом средствам индивидуализации, содержащим географические обозначения, посвящена лишь глава 11 Модельного Кодекса, закрепляющая общие положения о географических указаниях. Нормы Кодекса, регулирующие наименования мест происхождения товаров (далее - НМПТ), отсутствуют, в связи с чем предполагается их правовое регулирование национальными законодательствами странучастниц СНГ [2].

При этом нормы Модельного Кодекса о географических указаниях носят поверхностный характер, не затрагивают многие принципиально-важные вопросы и в большинстве своем отсылают к нормам национального законодательства, чем полностью оправдывает свой «модельный» характер.

В связи с вышеизложенным представляется важным и актуальным рассмотрение правового регулирования национальными законодательствами стран-участников СНГ вопросов, связанных с географическими указаниями и НМПТ.

В настоящее время в состав СНГ входят 9 государств: Азербайджан, Армения, Белоруссия, Казахстан, Киргизия, Молдавия, Россия, Таджикистан и Узбекистан. Рассмотрим каждое из них.

Азербайджан.

Законодательство Азербайджана в вопросе правого регулирования средств индивидуализации пошло по тому же пути, что и РФ в начале 90 -х годов двадцатого века, а именно принятия отдельных нормативно-правовых актов, регулирующих конкретную совокупность тем или иным образом связанных между собой средств индивидуализации. Правовое регулирование рассматриваемого нами вопроса в настоящее время ограничивается рамками Закона Азербайджанской республики от 12 июня 1998 года № 504-IQ «О товарных знаках и географических указаниях» (далее по тексту - Закон АР) [3].

Данный закон предусматривает правовую охрану лишь географических указаний, при этом о НМПТ не упоминается.

Принципиально важным в рамках настоящей статьи представляется то обстоятельство, что Закон Азербайджана не признает исключительных прав на географические указания (ст.25). Он лишь предусматривает возможность их использования по своему усмотрению (ст.26) [3].

\section{Армения.}

Главной особенностью правового регулирования законодательством Республики Армения вопросов, связанных с НМПТ и географическими указаниями, является применение наряду с ГК Республики Армения [4] специального Закона Республики Армения от 22.05.2010 г. № 3Р-60 «О географических указаниях» (далее по тексту Закон РА) [5].

При этом ГК РА применительно к рассматриваемы средствам индивидуализации товаров содержит лишь 7 статей, 5 из которых отсылают к Закону РА [5].

Закон Республики Армения включает в себя Общие положения, в том числе нормы, касающиеся компетентного органа (ст.5), которым является Агентство интеллектуальной собственности (обособленное подразделение, действующее в составе Министерства Экономики РА) [6], а также нормы о правовой охране и порядке государственной регистрации НМПТ и географических указаний.

При этом важным является то, что законодательство Республики Армения не признает исключительных прав за НМПТ и географическими указаниями, а лишь предоставляет право пользования ими (ч.2 ст.29 Закона РА), тогда как, например, на товарные знаки исключительное право признается (ст.1172 ГК РА) [5].

Белоруссия. 
Также, как и законодательство Республики Армения, законодательство Республики Беларусь в вопросе правового регулирования НМПТ и географических указаний пошло по пути рамочного регулирования в рамках ГК Республики Беларусь [7] и принятия специального Закона Республики Беларусь от 17.07.2002 №127-3 «О географических указаниях» (далее по тексту - Закон РБ) [8], содержащего подробное регулирование рассматриваемых нами средств индивидуализации.

Законом РБ от 18 декабря 2019 г. № 275-3 «Об изменении законов» [9] в Закон РБ и ГК РБ были внесены существенные изменения, и нормы, посвященные НМПТ и географическим указаниям, были изложены в новой редакции, в том числе НМПТ были признаны разновидностью географических указаний. При этом в отношении НМПТ было сохранено определение, данное в Законе РБ в редакции 2002 г. [10].

Законодательство РБ предусматривает существование в отношении НМПТ и географических указаний исключительных прав, которые включают право использовать их по своему усмотрению, а также запрещать их использование другим лицам, за исключением лиц, которым такое право предоставлено в соответствии с законодательством (ст.1026 ГК РБ) [8].

Казахстан.

Законодательство Республики Казахстан в вопросе правового регулирования НМПТ и географических указаний включает в себя ГК Республики Казахстан [11], предусматривающий общие положения и содержащий 5 статей, а также специальный Закон Республики Казахстан от 26 июля 1999 года № 456-I «О товарных знаках, знаках обслуживания и наименованиях мест происхождения товаров» (далее по тексту - Закон РК) [12].

Закон РК исчерпывающим образом регулирует вопросы, связанные с правовой охраной и регистрацией НМПТ, при этом предусматривает исключительное право владельца НМПТ на его использование любым, не противоречащих закону способом. Правовая охрана географических указаний законодательством РК не предусматривается. Кроме того, важным является отождествление ГК РК НМПТ и указаний происхождения, которые фактически признаются синонимами (п.1 ст.1033 ГК РК) [12].

\section{Киргизия.}

Как и законодательство Армении, Белоруссии и Казахстана, законодательство Киргизии по вопросу регулирования средств индивидуализации товаров делится на ГК Кыргызской Республики [13] и специальные законы, в том числе Закон Кыргызской Республики от 14 января 1998 года № 7 «О товарных знаках, знаках обслуживания и наименованиях мест происхождения товаров» (далее по тексту - Закон КР) [14].

Закон КР подробно регулирует основания возникновения и правовую охрану НМПТ, вместе с тем, ни он, ни ГК КР не предусматривают правовую охрану географических указаний и не упоминают данные средства индивидуализации товаров. При этом законодательством КР предусмотрено лишь предоставление владельцам НМПТ права пользования им, которое не является исключительным (ст.32 Закона КР) [14].

Молдавия.

Законодательство Республики Молдова в сфере интеллектуальной собственности ограничивается специальными законами, ГК Республики Молдова правовое регулирование по данным вопросам не осуществляется.

Применительно к рассматриваемым нами в рамках настоящей статьи средствам индивидуализации правовое регулирование осуществляется Законом Республики Молдова от 27 марта 2008 года №66-XVI «Об охране географических указаний, наименований мест происхождения и гарантированных традиционных продуктов» (далее по тексту - Закон РМ). Данный Закон устанавливает нормы, относящиеся к регистрации, правовой охране и использованию географических указаний, НМПТ, а 
также неизвестных законодательству РФ гарантированных традиционных продуктов, при этом за владельцем средства индивидуализации товаров признается право пользование данным средством индивидуализации (ст.10 Закона РМ) [15].

\section{Россия.}

Законодательство РФ по рассматриваемому в настоящей статье вопросу исчерпывается часть 4 ГК РФ, посвященной правам на результаты интеллектуальной деятельности и средства индивидуализации [16].

При этом Федеральным законом от 26.07.2019 № 230-Ф3 «О внесении изменений в часть четвертую ГК РФ и статьи 1 и 23.1 Федерального закона «О государственном регулировании производства и оборота этилового спирта, алкогольной и спиртосодержащей продукции и об ограничении потребления (распития) алкогольной продукции» правовая охрана была предоставлена новому средству индивидуализации наряду с ранее существовавшим НМПТ, а именно географическому указанию [17].

При этом ГК РФ предусматривает предоставление владельцу НМПТ или географического указания исключительное право на данное средство индивидуализации (ст.1519 ГК РФ) [16].

Таджикистан.

Ст.1126 ГК Республики Таджикистан предусматривает, что к объектам права интеллектуальной собственности относятся, в том числе, наименования мест происхождения товаров и указания происхождения, вместе с тем отдельных норм о рассматриваемых средствах индивидуализации не содержит [18].

Основная регулирующая роль отведена Закону Республики Таджикистан от 5 марта 2007 года № 236 «О географических указаниях» (далее по тексту - Закон РТ) [19].

При этом Закон РТ рассматривает географическое указание исключительно как собирательное понятие, которое включает в себя НМПТ и указания происхождения. В качестве отдельного средства индивидуализации товаров географические указание не выделяется.

Под указанием происхождения товара понимается обозначение, прямо или косвенно указывающее на место действительного происхождения или изготовления товара. Указание происхождения товара может быть представлено в виде названия географического объекта или изображения. Ему предоставляется правовая охрана наравне с НМПТ, при этом ни на указание происхождения товаров, ни на НМПТ не предоставляется исключительное право. Владельцы могут рассчитывать лишь на право пользования средством индивидуализации (ст.11 Закона РТ) [19].

\section{Узбекистан.}

Также, как и в большинстве стран-участницах СНГ законодательство Республики Узбекистан об объектах интеллектуальной деятельности и средствах индивидуализации пошло по пути принятия специальных законов, наравне с которыми базовые положения предусматриваются ГК Республики Узбекистан.

Основу правового регулирования составляет Закон Республики Узбекистан 30 августа 2001 года № 267-II «О товарных знаках, знаках обслуживания и наименованиях мест происхождения товаров» (далее по тексту - Закон РУ). Закон РУ предусматривает порядок предоставления правовой охраны НМПТ, при этом об иных средствах индивидуализации товаров, содержащих географические обозначения, не упоминается. Лицо, зарегистрировавшее НМПТ в РУ на основании выдаваемого свидетельства, приобретает право пользования таким НМПТ, которое не является исключительным [20].

На основании вышеизложенного, могут быть сделаны следующие выводы: 
1. Модели правового регулирования средств индивидуализации товаров, содержащих географические обозначения, в странах-участницах СНГ не отличаются единообразием.

Всего можно выделить три модели правового регулирования:

1) когда правовое регулирование осуществляется исключительно специальным законом;

2) когда наряду со специальным законом применяются нормы гражданского кодекса;

3) когда правовое регулирование осуществляется исключительно гражданским кодексом.

При этом вторая модель является преобладающей.

2. Отсутствует единообразие в предоставлении правовой охраны тем или иным средствам индивидуализации товаров, содержащих географические обозначения.

Напомним, что Модельный кодекс регулирует лишь географические указания, тогда как не все национальные законодательства предоставляют им правовую охрану.

На основе проведенного анализа можно выделить следующий перечень средств индивидуализации товаров, содержащих географические обозначения, которым предоставляется правовая охрана в странах-участницах СНГ:

1) НМПТ;

2) географические указания;

3) указания происхождения товаров;

4) гарантированные традиционные продукты.

При этом в отдельных случаях географическое указание выступает как собирательное понятие для обозначения иных средств индивидуализации.

3. Отсутствует единый подход к пониманию сущности предоставляемого на средства индивидуализации товаров, содержащих географические обозначения, праву.

Всего можно выделить два подхода:

1) когда предоставляется исключительное право;

2) когда предоставляется право пользования средством индивидуализации.

При этом преобладающим является второй подход.

Принимая во внимание отсутствие единообразия в законодательстве странучастниц СНГ, представляется очевидным, что цель принятия Модельного Кодекса в настоящее время нельзя считать достигнутой.

\section{$* * *$}

1. Шугурова, И.В. Модельное законотворчество в сфере интеллектуальной собственности в странах СНГ / И.В. Шугурова // Вестник Саратовской государственной юридической академии. 2014. № 3 (98). С. 131-137.

2. Модельный кодекс интеллектуальной собственности для государств-участников СНГ от 07.04.2010 г. // Информационный бюллетень. Межпарламентская Ассамблея государствучастников Содружества Независимых Государств. 2010. № 47. С. 133 - 183.

3. О товарных знаках и географических указаниях: Закон Азербайджанской Республики от 12 июня 1998 года № 504-IQ (ред. от 19.02.2019) [Электронный ресурс] URL: https://online.zakon.kz/Document/?doc_id=30598972\#pos=5;-106 Загл. с экрана. (дата обращения: 01.03.2021).

4. Гражданский кодекс Республики Армения от 28 июля 1998 года №3Р-239 (ред. от 30.12.2020) [Электронный pecypc] URL: https://base.spinform.ru/show_doc.fwx?rgn=2998 Загл. с экрана. (дата обращения: 01.03.2021).

5. О географических указаниях: Закон Республики Армения от 22.05.2010 г. № ЗР-60 (ред. от 29.06.2020) [Электронный pecypc] URL: https://base.spinform.ru/show_doc.fwx?rgn=67786 Загл. с экрана. (дата обращения: 01.03.2021).

6. Общая информация: сайт Агентства интеллектуальной собственности Республики Армения [Электронный pecypc]. URL: https://www.aipa.am/ru/about-us/ Загл. с экрана. (дата обращения: 01.03.2021). 
7. Гражданский кодекс Республики Беларусь от 7 декабря 1998 года № 218-3 (ред. от 29.06.2020) [Электронный ресурс] URL: https://online.zakon.kz/document/?doc_id=30415161\#pos=6;-106 Загл. с экрана. (дата обращения: 01.03.2021).

8. О географических указаниях: Закон Республики Беларусь от 17 июля 2002 года № 127-3 (ред. от 18.12.2019) [Электронный ресурс] URL: https://online.zakon.kz/Document/?doc_id=30539316 Загл. с экрана. (дата обращения: 01.03.2021).

9. Об изменении законов: Законом Республики Беларусь от 18 декабря 2019 г. № 275-3 [Электронный ресурс] URL: https:/pravo.by/document/?guid=3961\&p0=H11900275 Загл. с экрана. (дата обращения: 01.03.2021).

10. Профессионально об актуальном: Новая редакция Закона «О географических указаниях». Часть 1: Национальный правовой интернет-портал Республики Беларусь [Электронный ресурс]. URL: https://pravo.by/novosti/novosti-pravo-by/2020/mart/47897/ Загл. с экрана. (дата обращения: 01.03.2021).

11. Гражданский кодекс Республики Казахстан (Особенная часть) от 1 июля 1999 года № 409-I (ред. от 02.01.2021) [Электронный pecypc] URL: https://online.zakon.kz/m/document/?doc_id=1013880 Загл. с экрана. (дата обращения: 01.03.2021).

12. О товарных знаках, знаках обслуживания и наименованиях мест происхождения товаров: Закон Республики Казахстан от 26 июля 1999 года № 456-I (ред. от 21.01.2019) [Электронный ресурс] URL: https://online.zakon.kz/document/?doc_id=1014203 Загл. с экрана. (дата обращения: 01.03.2021).

13. Гражданский кодекс Кыргызской Республики от 5 января 1998 года № 1 (Часть II) (ред. от 19.04.2019) [Электронный ресурс] URL: https://online.zakon.kz/document/?doc_id=30224035\#pos=6;-106 Загл. с экрана. (дата обращения: 01.03.2021).

14. О товарных знаках, знаках обслуживания и наименованиях мест происхождения товаров: Закон Кыргызской Республики от 14 января 1998 года № 7 (ред. от 23.03.2020) [Электронный ресурс] URL: https://online.zakon.kz/document/?doc_id=30223739 Загл. с экрана. (дата обращения: 01.03.2021).

15. Об охране географических указаний, наименований мест происхождения и гарантированных традиционных продуктов: Законом Республики Молдова от 27 марта 2008 года №66-XVI (ред. от 24.05.2018) [Электронный ресурс] URL: https://base.spinform.ru/show_doc.fwx?rgn=24075 Загл. с экрана. (дата обращения: 01.03.2021).

16. Гражданский кодекс Российской Федерации (часть четвертая): федер. закон от 18.12.2006 № 230 Ф3 // Парламентская газета. 2006. № 214-215; Российская газета. 2019. № 158. (ред. от 30.12.2020).

17. О внесении изменений в часть четвертую Гражданского кодекса Российской Федерации и статьи 1 и 23.1 Федерального закона «О государственном регулировании производства и оборота этилового спирта, алкогольной и спиртосодержащей продукции и об ограничении потребления (распития) алкогольной продукции»: федер. закон от 26.07.2019 г. № 230-Ф3 // Собр. Законодательства Рос. Федерации. 2019. №30. Ст.4132.

18. Гражданский кодекс Кыргызской Республики от 1 марта 2005 года (Часть третья) (ред. от 03.07.2012) [Электронный ресурс] URL: https://online.zakon.kz/document/?doc_id=30447965 Загл. с экрана. (дата обращения: 01.03.2021).

19. О географических указаниях: Закон Республики Таджикистан от 5 марта 2007 года № 236 (ред. от 02.01.2019) [Электронный ресурс] URL: https://online.zakon.kz/Document/?doc_id=30593669 Загл. с экрана. (дата обращения: 01.03.2021).

20. О товарных знаках, знаках обслуживания и наименованиях мест происхождения товаров: Закон Республики Узбекистан 30 августа 2001 года № 267-II (ред. от 05.10.2020) [Электронный ресурс] URL: https://online.zakon.kz/Document/?doc_id=30433212 Загл. с экрана. (дата обращения: 01.03.2021).

\section{Обыденная А.И., Голенок С.Г. \\ Правовое регулирование смарт-контрактов в законодательстве Российской Федерации}

Петрозаводский государственный университет (Россия, Петрозаводск)

doi: 10.18411/lj-04-2021-241

\section{Аннотация}

Статья посвящена вопросам правового регулирования смарт-контрактов в ходе реформы, направленной на цифровизацию гражданского законодательства. В статье 